\title{
PENGARUH DISIPLIN DAN KEPEMIMPINAN DIRI DENGAN KINERJA PEGAWAI DIREKTORAT PERKAPALAN DAN KELAUTAN
}

\author{
Bobi satria $^{1}$, Aprizawati $^{2}$, Romadhoni $^{3}$ \\ Politeknik Negeri Bengkalis ${ }^{1,2,3}$ \\ bobisatria@polbeng.ac.id ${ }^{1}$
}

\begin{abstract}
ABSTRAK
Tujuan penelitian ini untuk mengetahui pengaruh disiplin dan kepemimpinan diri dengan kinerja pegawai Direktorat Perkapalan dan Kelautan. Metode penelitian yang digunakan dalam penelitian ini adalah survai dengan jenis penelitian korelasional. Hasil penelitian menunjukkan nilai koefisien korelasi antara gaya kepemimpinan dengan kinerja karyawan adalah sebesar 0,613, gaya kepemimpinan dapat memberikan kontribusinya untuk meningkatkan kinerja karyawan yaitu $37,5 \%$. Selanjutnya nilai koefisien korelasi antara disiplin kerja dengan kinerja karyawan adalah sebesar 0,710, artinya disiplin kerja juga memberikan kontribusi yang cukup tinggi untuk meningkat kinerja karyawan yaitu 50,4\%. Selanjutnya hasil korelasi dan regresi ganda atas gaya kepemimpinan, dan disiplin kerja secara bersama-sama dengan kinerja karyawan diperoleh besar koefisien korelasi sebesar 0,759 atau 57,6\%. Simpulan, ketiga variabel bebas gaya kepemimpinan (X1), dan disiplin kerja (X2), merupakan variabel yang perlu diperhatikan. Dengan kata lain, bahwa ketiga variabel bebas gaya kepemimpinan (X1), dan disiplin kerja (X2) adalah variabel yang cukup efektif untuk meningkatkan kinerja karyawan.
\end{abstract}

Kata Kunci : Disiplin, Kepemimpinan, Kinerja, Pelayanan

\begin{abstract}
The purpose of this study was to determine the effect of discipline and selfleadership on the performance of the Directorate of Shipping and Maritime employees. The research method used in this study is a survey with the type of correlational research. The results showed the value of the correlation coefficient between leadership style and employee performance amounted to 0.613, leadership style can contribute to improving employee performance that is $37.5 \%$. Furthermore, the correlation coefficient between work discipline and employee performance is 0.710 , meaning that work discipline also contributes high enough to improve employee performance by 50.4\%. Furthermore, the results of correlation and multiple regression of leadership style, and work discipline together with employee performance obtained a large correlation coefficient of 0.759 or $57.6 \%$. In conclusion, the three independent variables are leadership style (X1), and work discipline (X2), which are variables that need attention. In other words, that the three independent variables are leadership style (X1), and work discipline $(X 2)$ are variables that are effective enough to improve employee performance.
\end{abstract}

Keywords: Discipline, Leadership, Performance, Service 


\section{PENDAHULUAN}

Kelancaran penyelenggaraan tugas Pemerintah dengan kesempurnaan Aparatur Negara terutama Pegawai. Oleh karena itu, dalam mencapai suatu tujuan pembangunan yakni mewujudkan masyarakat yang makmur, adil dan bermoral tinggi diperlukan Pegawai yang bertugas memberikan pelayanan secara adil dan merata kepada masyarakat (Paul, 2004).

Pegawai merupakan bagian dari suatu kemajuan ilmu, pembangunan, dan teknologi.Oleh karena itu dalam era sekarang ini dimana teknologi dan peradaban sudah sangat maju, menuntut Pegawai yang kompeten serta memiliki semangat dan kedisiplinan yang tinggi dalam menjalankan peran dan fungsinya baik untuk individual maupun tujuan organisasial. Setiap Pegawai mempunyai potensi untukbertindak dalam berbagaibentuk aktivitas. Kemampuan bertindak itu dapat diperoleh Pegawai baik secara alami (ada sejak lahir) atau dipelajari. Walaupun pegawai mempunyai potensi untuk berperilaku tertentu tetapi perilaku itu hanya diaktualisasi pada saat-saat tertentu saja.Potensi untuk berperilaku tertentu itu disebut ability (kemampuan), sedangkan ekspresi dari potensi ini dikenal sebagai performance (kinerja) (Fahmi, 2009).

Kinerja Pegawai pada dasarnya terbentuk setelah Pegawai merasa adanya kepuasan karena kebutuhannya terpenuhi, dengan kata lain apabila kebutuhan pegawai belum terpenuhi sebagaimana mestinya maka kepuasan kerja tidak akan tercapai, dan pada hakikatnya kinerja Pegawai akan sulit terbentuk (Nurita, 2008).

Disiplin kerja adalah merupakan modal penting yang harus dimiliki oleh Aparatur Negara/Pegawai Negeri Sipil (PNS) sebab menyangkut pemberian pelayanan publik.Namun ironisnya, kualitas etos kerja dan disiplin kerja Pegawai Negeri Sipil (PNS) secara umum masih tergolong rendah hal ini disebabkan banyaknya permasalahan yang dihadapi oleh para Pegawai Negeri Sipil (PNS). Permasalahan tersebut antara lain kesalahan penempatan dan ketidakjelasan jalur karier yang ditempuh namun Pemerintahan terus berusaha melakukan reformasi birokrasi di Instansi Pemerintahan (Aritonang, 2005).

Permasalahan kedisiplinan merupakan persoalan yang tidak pernah terselesaikan. Masalah kedisiplinan Pegawai ini, merupakan persoalan serius karena masih ada Pegawai yang terkesan malas-malasan melaksanakan tugasnya. Bahkan tidak sedikit Pegawai yang berkeliaran di saat jam kerja. Peraturan disiplin Pegawai Negeri Sipil (PNS) adalah peraturan yang mengatur kewajiban, larangan dan sanksi apabila kewajiban-kewajiban tidak ditaati atau dilanggar oleh Pegawai Negeri Sipil (PNS).Dengan maksud untuk mendidik dan membina Pegawai Negeri Sipil (PNS), bagi mereka yang melakukan pelanggaran atas kewajiban dan larangan dikenakan sanksi berupa Hukuman Disiplin.Pegawai Negeri Sipil (PNS) sebagai unsur Aparatur Negara dalam menjalankan roda Pemerintahan dituntut untuk melaksanakan fungsi dan tugasnya sebagai Abdi Negara dan Abdi Masyarakat. Pegawai Negeri Sipil (PNS) juga harus bisa menjunjung tinggi martabat dan citra kepegawaian demi kepentingan masyarakat dan negara namun kenyataan di lapangan berbicara lain dimana masih banyak ditemukan Pegawai Negeri Sipil (PNS) yang tidak menyadari akan tugas dan fungsinya tersebut sehingga seringkali timbul ketimpangan-ketimpangan dalam menjalankan tugasnya dan tidak jarang pula menimbulkan kekecewaan yang berlebihan pada masyarakat (Setiawan, 2006). 
Hal yang tak perlu disangkal lagi, faktor kedisiplinan memegang peranan yang amat penting dalam pelaksanaan tugas sehari-hari para Pegawai. Seorang Pegawai yang mempunyai tingkat kedisiplinan yang tinggi akan tetap bekerja dengan baik walaupun tanpa diawasi oleh atasan. Seorang pegawai yang disiplin tidak akan mencuri waktu kerja untuk melakukan hal-hal lain yang tidak ada kaitannya dengan pekerjaan. Disiplin adalah meletakkan segala sesuatu pada setiap tempatnya. Bila tidak menjaga kedisiplinan maka akan mendapatkan beberapa masalah yang dapat mempengaruhi kinerja. Sebagai Pemimpin yang baik, disiplin itu harus ditanamkan dalam jiwa Pemimpin (Tampubolon, 2007).

Salah satu elemen yang bernilai penting dalam sistem manajemen selain disiplin kerja kepada para Pegawai adalah Kepemimpinan Diri. Kepemimpinan Diri adalah suatu proses dimana seseorang dapat menjadi Pemimpin (Leader) melalui aktivitas yang terus menerus sehingga dapat mempengaruhi yang dipimpinnya (followers) dalam rangka untuk mencapai tujuan organisasi (Suganda, 2001).

Kepemimpinan Diri seseorang ditandai dengan mampu menembus ketidakpastian menjadi peluang, oleh karena itu membangun kebiasaan yang produktif merupakan kunci menuju sukses dalam menembus gonjangangonjongan yang ditimbulkan oleh faktor internal dan faktor eksternal, disinilah dituntut kemampuan kepemimpinan dapat mengelola dampak konflik dalam menanggapi kepentingan masyarakat. Kepemimpinan Diri sangat dibutuhkan untuk menghadapi perubahan lingkungan yang cepat dan membutuhkan daya fleksibelitas, respon cepat, kreativitas dan keterampilan belajar yang baik. Oleh karena itulah pengembangan kemampuan pribadi untuk menjadi Pemimpin dirinya sendiri penting untuk dilakukan.

\section{METODE PENELITIAN}

Metode penelitian yang digunakan dalam penelitian ini adalah survai dengan jenis penelitian korelasional yaitu salah satu jenis penelitian yang dirancang untuk menentukan tingkat hubungan antara variabel-variabel yang berbeda dalam suatu populasi.

Variabel-variabel penelitian ini terdiri dari atas dua variabel prediktor dan satu variabel kriterium. Variabel prediktor adalah 1) disiplin kerja, dan motivasi kerja pegawai. 2) sedangkan variabel kriterium adalah kinerja pegawaiDirektorat Perkapalan dan Kelautan.

Konstelasi model permasalaan mengenai hubungan antara perawatan armada dan motivasi kerja pegawai dengan kinerja pegawai Direktorat Perkapalan dan Kelautan.

\section{Teknik Pengumpulan Data}

Data yang dikumpulkan dalam penelitian ini ada 3 (tiga) macam, sesuai dengan variable yang diteliti; yaitu data tentang kinerja pegawaiDirektorat Perkapalan dan Kelautan (sebagai variable terikat), disiplin kerja, dan motivasi kerja pegawai(sebagai variable bebas).

Pengumpulan data dilakukan melalui 3 (tiga) instrumen. Dan ketiga instrumen tersebut berbentuk angket (kuesioner) dilaksanakan dengan cara responden merespon sendiri instrumen yang diberikan kepada mereka. Hal ini dilakukan karena semua responden yang terdiri dari pegawaiDirektorat 
Perkapalan dan Kelautan sama yang tidak diragukan lagi keberadaan mereka di perusahaan tersebut. Sehingga tidak ada hambatan dalam menjawab dan mengisi angket tersebut.

\section{Instrumen Penelitian}

Penelitian ini meneliti 3 (tiga) variabel yaitu kinerja pegawai Direktorat Perkapalan dan Kelautanmm(Y) sebagai variabel kriterium. Gaya kepemipinan $\left(\mathrm{X}_{1}\right)$ dan motivasi kerja pegawai $\left(\mathrm{X}_{2}\right)$ masing-masing sebagai variabel prediktor. Instrumen penelitian untuk mengukur ketiga variabel tersebut akan dijelaskan satu persatu dimulai dari variabel kriterium sampai variabel prediktor sebagai berikut:

\section{Teknik Analisis Data}

Data yang terkumpul dilakukan analisis dengan menggunakan statistik sebagai berikut; (1) deskripsi data yang meliputi rata-rata, rentangan, standar deviasi, median, modus dan dilengkapi dengan frekuensi dan histogram, (2) pengujian persyaratan analisis yaitu meliputi pengujian normalitas dan uji homogenitas varians, dan (3) pengujian hipotesis dilakukan dengan menggunakan analisis regresi dan korelasi sederhana utuk masing variabel bebas terhadap variable terikat, dan regresi ganda untuk seluruh variable bebas dengan variable terikat, serta korelasi ganda dan parsial.

\section{HASIL PENELITIAN}

\section{Hubungan Disiplin $\left(\mathrm{X}_{1}\right)$ dengan Kinerja $(\mathrm{Y})$}

Tabel 1 Analisis Variansi untuk Regresi Linear $\mathrm{Y}$ atas $\mathrm{X}_{1}$ dengan Persamaan $\hat{\mathrm{Y}}=19,108+0,804 \mathrm{X}_{1}$

\begin{tabular}{|c|c|c|c|c|c|c|}
\hline \multirow{2}{*}{$\begin{array}{l}\text { Sumber } \\
\text { Variansi }\end{array}$} & \multirow[t]{2}{*}{$\mathrm{dk}$} & \multirow[t]{2}{*}{ JK } & \multirow[t]{2}{*}{ RJK } & \multirow[t]{2}{*}{$\mathrm{F}_{\text {hitung }}$} & \multicolumn{2}{|c|}{$\mathrm{F}_{\text {tabel }}$} \\
\hline & & & & & \multirow[t]{2}{*}{$\alpha=0,05$} & \multirow[t]{2}{*}{$\alpha=0,01$} \\
\hline Total direduksi & 29 & 994,700 & & & & \\
\hline Regresi & 1 & 494,657 & 494,657 & $27,698 * *$ & 4,02 & 7,12 \\
\hline Sisa & 28 & 500,043 & 17,859 & & & \\
\hline Tuna cocok & 14 & 271.043 & 19,360 & $1.184^{\mathrm{ns}}$ & 1,84 & 2,38 \\
\hline Galat & 14 & 229.000 & 16,357 & & & \\
\hline \multicolumn{7}{|l|}{ Keterangan : } \\
\hline \multicolumn{7}{|c|}{$* *=$ sangat signifikan $F_{\text {hitung }}(27,698)>F_{\text {tabel }}(7,12)$} \\
\hline \multirow{2}{*}{\multicolumn{7}{|c|}{$\begin{array}{ll}\mathrm{ns} & =\text { tidak signifikan } \mathrm{F}_{\text {hitung }}(1,184)<\mathrm{F}_{\text {tabel }}(1,84), \text { regresi linear } \\
\mathrm{dk} & =\text { derajat kebebasan }\end{array}$}} \\
\hline & & & & & & \\
\hline \multicolumn{7}{|c|}{$\mathrm{JK}=$ Jumlah Kuadrat } \\
\hline \multicolumn{7}{|c|}{ RJK = Rata-rata Kuadrat Jumlah } \\
\hline
\end{tabular}

Hasil pengujian signifikansi regresi menunjukkan $F_{h}=27,698>F_{(0,01 ; 1 / 28)}=$ 7,12 dan hasil pengujian kelinearan regresi menunjukan $\mathrm{F}_{\mathrm{h}}=1,184<\mathrm{F}_{\mathrm{t}(0,05 ; 20 / 8)}=$ 1.84, yang berarti regresi Kinerja $(\mathrm{Y})$ atas Disiplin $\left(\mathrm{X}_{1}\right)$ sangat signifikan dan hubungan keduanya bersifat linear. Dengan demikian maka Disiplin merupakan salah satu prediktor Kinerja . Persamaan garis regresiŶ $=19,108+$ $0,804 \mathrm{X}_{1}$ mengandung arti bahwa setiap kenaikan satu skor Disiplin akan menyebabkan kenaikan satu skor Kinerja sebesar 0,804 pada kostanta 19,108. Untuk jelasnya bentuk hubungan tersebut dapat divisualisasikan pada gambar 1 . 


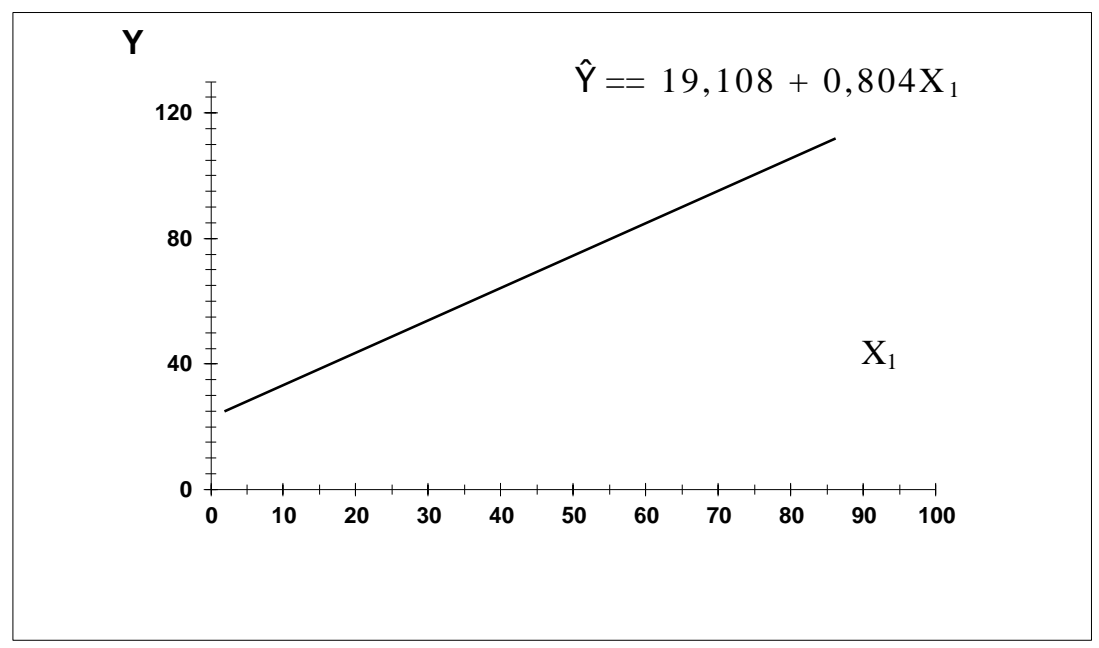

Keterangan:

Gambar 1. Grafik hubungan Disiplin dengan Kinerja

Jika tidak terdapat pengaruh Disiplin maka skor Kinerja 19,108

Jika skor Disiplin satu, maka Kinerja menjadi 20,108

Jika skor Disiplin dua, maka skor Pengembangan karie rmenjadi 21,108

Kekuatan hubungan antara disiplin dengan kinerja dapat ditunjukkan oleh koefisien korelasi ry 1 sebesar 0,705. Hasil uji signifikan koefisien korelasi antara variabel tersebut terlihat pada tabel 2.

Tabel 2 Uji Signifikansi Koefisien Korelasi antara Disiplin $\left(\mathrm{X}_{1}\right)$ dengan Variabel Kinerja (Y)

\begin{tabular}{ccccrr}
\hline $\mathrm{n}$ & $\begin{array}{c}\text { Koefisien Korelasi } \\
\left(\mathrm{ry}_{1}\right)\end{array}$ & $\begin{array}{c}\text { Koefisien } \\
\text { Determinitasi }\end{array}$ & $\mathrm{t}_{\text {hitung }}$ & \multicolumn{2}{c}{$\mathrm{t}_{\text {tabel }}$} \\
\hline 30 & 0,705 & 0,3497 & $5,263 * *$ & 0,05 & 0,01 \\
\hline$* *$ Signifikan pada $\alpha=0,05$ & & & &
\end{tabular}

Hasil pengujian berarti koefisien korelasi menunjukkan bahwa hubungan antara Disiplin $\left(\mathrm{X}_{1}\right)$ dengan Variabel Kinerja $(\mathrm{Y})$ bersifat positif dan sangat signifikan, dengan kata lain semakin tinggi Disiplin karyawan, semakin baik pula Kinerja . Dengan demikian mka menerima hipotesis pertama yang menyatakan: "terdapat hubungan yang positif antara Disiplin $\left(\mathrm{X}_{1}\right)$ dengan Variabel Kinerja (Y)." Koefisien determinasi sebesar 0,497 menunjukkan bahwa 49,7\% varians yang terjadi pada Kinerja, dijelaskan oleh disiplin melalui regresi persamaan garis $\hat{Y}=19,108+0,804 X_{1}$.

Tabel 3 Korelasi Y atas $\mathrm{X}_{1}$ Jika Variabel $\mathrm{X}_{2}$ dikontrol

\begin{tabular}{lccccc}
\hline $\mathrm{N}$ & $\begin{array}{c}\text { Korelasi } \\
\text { Parsial }\end{array}$ & $\begin{array}{c}\text { Koefisien Korelasi } \\
\text { Parsial }\end{array}$ & $\mathrm{t}_{\text {hitung }}$ & 0,05 & 0.01 \\
\hline 30 & $\mathrm{r}_{\mathrm{y} 1.2}$ & 0,563 & 3.539 & 1,67 & 2,39 \\
\hline Keterangan: & & & & \\
$* * \quad=$ sangat signifikan & & & \\
$\mathrm{r}_{\mathrm{y} 1.2} \quad=$ Koefisien korelasi $\mathrm{Y}$ dan $\mathrm{X}_{1}$ jika $\mathrm{X}_{2}$ dikontrol &
\end{tabular}


Pengontrolan variabel kepemimpinan diri memberi efek menurunkan Disiplin dengan korelasi kinerja dari 0,705 menjadi 0,563. Uji signifikan koefisien parsial menunjukkan bahwa $t_{h}=3,539>t_{t}(0,01 ; 28)=0,00$ yang berarti koefisien korelasi Disiplin dengan kinerja jika kepemimpinan diri dikontrol adalah tetap sangat signifikan.

\section{Hubungan Kepemimpinan diri $\left(\mathrm{X}_{2}\right)$ dengan Kinerja $(\mathrm{Y})$.}

Tabel 4 Analisis Variansi untuk Regresi Linear Y atas $\mathrm{X}_{2}$ Dengan Persamaan $\hat{Y}=23,012+0,785 X_{2}$

\begin{tabular}{lcccccc}
\hline $\begin{array}{l}\text { Sumber } \\
\text { Variansi }\end{array}$ & $\mathrm{dk}$ & $\mathrm{JK}$ & $\mathrm{RJK}$ & $\mathrm{F}_{\text {hitung }}$ & \multicolumn{2}{c}{$\mathrm{F}_{\text {tabel }}$} \\
\hline Total direduksi & 29 & 994,700 & & & $\alpha=0,05$ & $\alpha=0,01$ \\
Regresi & 1 & 1186.255 & 1186.255 & $33,572^{* *}$ & 4,02 & 7,12 \\
Sisa & 28 & 1165.912 & 41.640 & & & \\
Tuna cocok & 17 & 262,506 & 15,442 & $0,895^{\mathrm{ns}}$ & 1,84 & 2,38 \\
Galat & 11 & 189,833 & 17,258 & & & \\
\hline
\end{tabular}

Keterangan :

$* *$ = sangat signifikan $F_{\text {hitung }}(33,572)>F_{\text {tabel }}(7,12)$

ns $=$ tidak signifikan $F_{\text {hitung }}(0,895)<\mathrm{F}_{\text {tabel }}(1,84)$, regresi linear

$\mathrm{dk}=$ derajat kebebasan

$\mathrm{JK}=$ Jumlah Kuadrat

RJK= Rata-rata Kuadrat Jumlah

Tabel 4 menunjukkan bahwa persamaan regresi $\hat{Y}=23,012+0,785 \mathrm{X}_{2}$ signifikan pada taraf $\alpha=0,05$. Hal ini menyebabkan hipotesis nol ditolak dan hipotesis penelitian diterima, karena $F_{\text {hitung }}=33,572>F_{\text {tabel }(1 ; 28)}=7,27$. Dengan demikian persamaan regresi $\hat{Y}=23,012+0,785 \mathrm{X}_{2}$ signifikan.

Hasil linearitas menunjukkan bahwa hipotesis nol diterima dan hopotesis alternatif ditolak, karena $F_{h}=0,895<F_{t}(0,05 ; 17 / 11)=1,84$. Oleh karena itu persamaan regresi $\mathrm{Y}=23,012+0,785 \mathrm{X}_{2}$ berbentuk linear. Persamaan ini mempunyai arti bahwa setiap kenaikan satu skor Kepemimpinan diri akan menyebabkan kenaikan Kinerja sebesar 0,785pada kostanta 23,012.

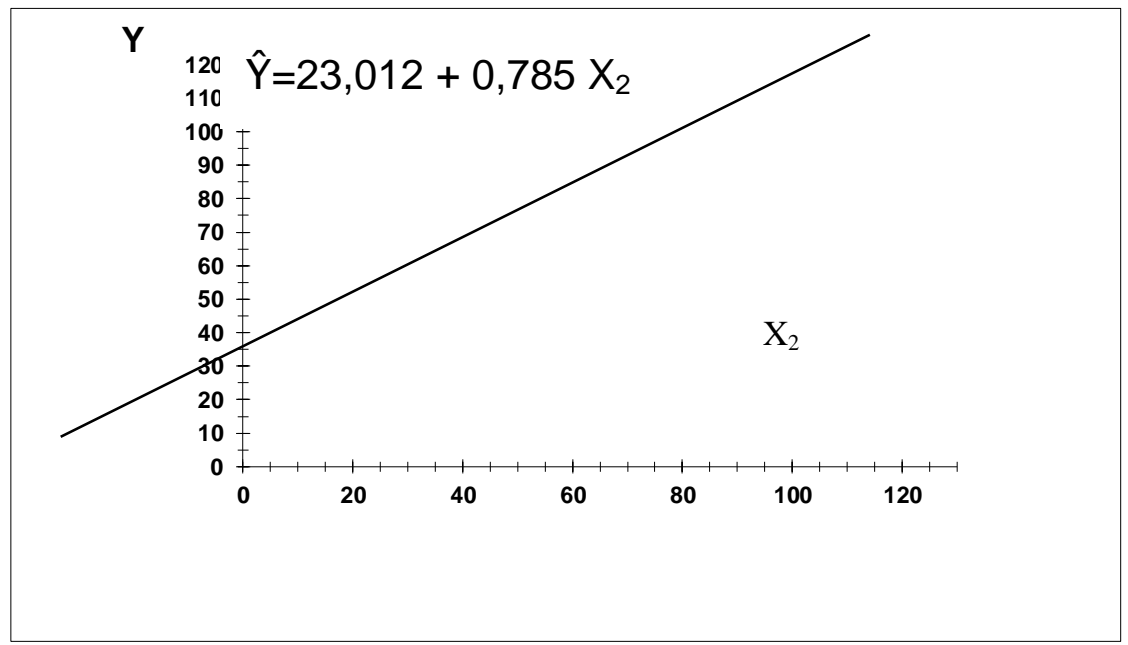


Gambar 2 Grafik hubungan Kepemimpinan diri dengan Kinerja

Keterangan:

Jika tidak terdapat pengaruh kepemimpinan diri maka skor Kinerja sebesar 23,012

Jika skor Kepemimpinan diri seratus maka skor Kinerja menjadi 123,012

Kekuatan hubungan antara Kepemimpinan diri (X2) dengan Kinerja (Y) dapat ditunjukkan oleh koefisien korelasi ry 2 sebesar 0,738 .

Tabel 5 Uji Signifikansi Koefisien Korelasi Antara Variabel Kepemimpinan diri $\left(\mathrm{X}_{2}\right)$

\begin{tabular}{cccccr}
\multicolumn{3}{c}{ dengan Variabel Kinerja } & $(\mathrm{Y})$ \\
\hline $\mathrm{N}$ & $\begin{array}{c}\text { Koefisien Korelasi } \\
\left(\mathrm{ry}_{2}\right)\end{array}$ & $\begin{array}{c}\text { Koefisien } \\
\text { Determinitasi }\end{array}$ & $\mathrm{t}_{\text {hitung }}$ & \multicolumn{3}{c}{$\mathrm{t}_{\text {tabel }}$} \\
\hline 30 & 0,738 & 0,545 & $5,337 * *$ & 1,67 & 2,39 \\
\hline$* *$ Signifikan pada $\alpha=0,05$ & & & &
\end{tabular}

Hasil pengujian tersebut menunjukkan bahwa hubungan antara Kepemimpinan diri $\left(\mathrm{X}_{2}\right)$ dengan Kinerja $(\mathrm{Y})$ bersifat positif dan sangat signifikan. Artinya, semakin baik Kepemimpinan diri atau perusahaan makin tinggi Kinerja . Koefisien determinisasi $\left(\mathrm{r}_{\mathrm{y} 2}\right)^{2}=0,545$ menunjukkan bahwa 54,5\% varians yang terjadi pada Kinerja dapat dijelaskan melalui kepemimpinan diri. Dengan demikian maka menerima hipotesis kedua yang menyatakan : "terdapat hubungan positif antara Kepemimpinan diri dengan Kinerja ."

Tabel 6 Korelasi $\mathrm{Y}$ atas $\mathrm{X}_{2}$ Jika Variabel $\mathrm{X}_{1}$ dikontrol

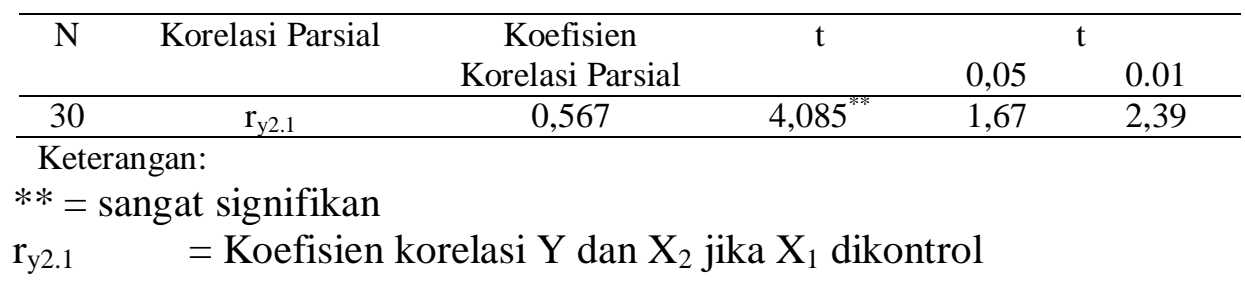

Pengontrolan variabel Disiplin memberi efek menurunnya koefisien korelasi Kepemimpinan diri dengan Kinerja dari 0,738 menjadi 0,567. Hasil uji signifikansi koefisien korelasi parsial membuktikan bahwa $\mathrm{t}_{\mathrm{h}}=4,085>\mathrm{t}_{\mathrm{t}(0,05 ; 28)}=$ 1,67 yang berarti koefisien korelasi kepemimpinan diri terhadap preusahaan dengan Kinerja tetap signifikan walaupun Disiplin dikontrol melalui uji korelasi parsial.

\section{Hubungan antara Disiplin, dan Kepemimpinan Diri Secara bersama-sama dengan Kinerja}

Tabel 7 ANAVA untuk Uji Signifikansi dan Linearitas Regresi Ganda dengan Persamaan Regresi $=4,703+0,505 \mathrm{X}_{1}+0,543 \mathrm{X}_{2}$

\begin{tabular}{lcccccc}
\hline Sumber Variasi & Dk & \multicolumn{1}{c}{ JK } & RJK & $F_{\text {hit }}$ & \multicolumn{2}{c}{$F_{\text {tabel }}$} \\
\hline Total & 29 & 994,700 & - & - & $\alpha=0,05$ & $\alpha=0,01$ \\
Regresi & 2 & 685,682 & 342,841 & $29,955^{* *}$ & 4,07 & 7,27 \\
Sisa & 27 & 309,108 & 11,445 & & & \\
\hline
\end{tabular}




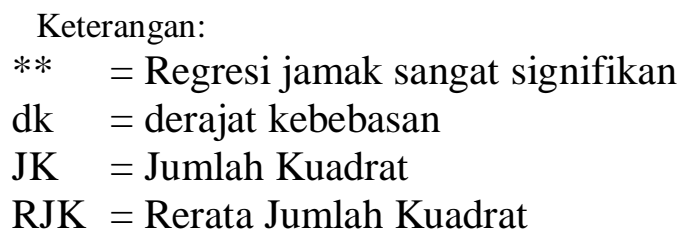

Hasil pengujian signifikansi regresi adalah $F_{h}=29,955>F_{(0,01 ; 2 / 27)}=7,271$. Hal ini menunjukkan bahwa regresi Kinerja $(\mathrm{Y})$ atas Disiplin $\left(\mathrm{X}_{1}\right)$, dan Kepemimpinan diri $\left(\mathrm{X}_{2}\right)$ sangat signifikan. Hal ini berarti Disiplin, dan Kepemimpinan diri secara bersama-sama merupakan prediktor Kinerja .

Persamaan regresi $\hat{Y}=4,703+0,505 \mathrm{X}_{1}+0,543 \mathrm{X}_{2}$, menunjukan bahwa setiap pertambahan satu skor pada variabel Disiplin, dan Kepemimpinan diri secara bersama-sama, dapat menyebabkan pertambahan Kinerja . Kekuatan hubungan antara variabel-variabel tersebut ditunjukkan oleh koefisien korelasi ganda sebesar 0,830 .

Tabel 8 Uji Keberartian Koefisien Korelasi Ganda Disiplin $\left(\mathrm{X}_{1}\right)$, dan Kepemimpinan diri $\left(\mathrm{X}_{2}\right)$ secara bersama-sama dengan Kinerja (Y)

\begin{tabular}{cccccc}
\hline $\mathrm{N}$ & Korelasi & $\begin{array}{c}\text { Koefisien } \\
\text { Korelasi Ganda }\end{array}$ & $\mathrm{F}_{\text {hitung }}$ & \multicolumn{2}{c}{$\mathrm{F}_{\text {tabel }}$} \\
& $\mathrm{R}_{\mathrm{y} .12}$ & 0,830 & 29,955 & 4,07 & 7,27 \\
\hline 30 & & & &
\end{tabular}

Hasil pengujian menunjukkan bahwa hubungan antara Disiplin, dan Kepemimpinan diri secara bersama-sama bersifat positif dan sangat signifikan, dengan koefisien determinasi sebesar 0,689. Temuan ini menunjukkan bahwa semakin tinggi Disiplin, dan Kepemimpinan diri secara bersama-sama, maka akan semakin meningkat pula Kinerja, 68,9\% varians yang terjadi pada Kinerja , dijelaskan secara bersama-sama oleh variabel $\mathrm{X}_{1}$ dan $\mathrm{X}_{2}$ melalui persamaan garis regresi $\hat{Y}=4,703+0,505 X_{1}+0,543 X_{2}$. Hasil pengujian regresi dan korelasi ganda tersebut membuktikan terdapat hubungan positif antara Disiplin, dan Kepemimpinan diri secara bersama-sama dengan Kinerja.

Tabel 9 Peringkat Kekuatan Hubungan Variabel Bebas dengan Variabel Terikat Berdasarkan Koefisien Korelasi Parsial

\begin{tabular}{cccc}
\hline $\mathrm{N}$ & $\begin{array}{c}\text { Korelasi } \\
\text { Parsial }\end{array}$ & $\begin{array}{c}\text { Koefisien } \\
\text { Korelasi Parsial }\end{array}$ & Peringkat \\
\hline 30 & $\mathrm{r}_{\mathrm{y} 1.2}$ & 0,563 & Kedua \\
30 & $\mathrm{r}_{\mathrm{y} 2.1}$ & 0,618 & Pertama \\
\hline
\end{tabular}

$\begin{array}{ll}\text { Keterangan: } & \text { Koefisien korelasi } Y \text { dan } X_{1} \text { jika } X_{2} \text { dikontrol } \\ r_{\mathrm{y} 1,2} & =\text { Koefisien korelasi } Y \text { dan } X_{2} \text { jika } X_{1} \text { dikontrol } \\ r_{\mathrm{y} 2,1} & \end{array}$

\section{PEMBAHASAN}

Permasalahan kedisiplinan merupakan persoalan yang tidak pernah terselesaikan. Masalah kedisiplinan Pegawai ini, merupakan persoalan serius karena masih ada Pegawai yang terkesan malas-malasan melaksanakan tugasnya. Bahkan tidak sedikit Pegawai yang berkeliaran di saat jam kerja. Peraturan 
disiplin Pegawai Negeri Sipil (PNS) adalah peraturan yang mengatur kewajiban, larangan dan sanksi apabila kewajiban-kewajiban tidak ditaati atau dilanggar oleh Pegawai Negeri Sipil (PNS).Dengan maksud untuk mendidik dan membina Pegawai Negeri Sipil (PNS), bagi mereka yang melakukan pelanggaran atas kewajiban dan larangan dikenakan sanksi berupa Hukuman Disiplin.Pegawai Negeri Sipil (PNS) sebagai unsur Aparatur Negara dalam menjalankan roda Pemerintahan dituntut untuk melaksanakan fungsi dan tugasnya sebagai Abdi Negara dan Abdi Masyarakat. Pegawai Negeri Sipil (PNS) juga harus bisa menjunjung tinggi martabat dan citra kepegawaian demi kepentingan masyarakat dan negara namun kenyataan di lapangan berbicara lain dimana masih banyak ditemukan Pegawai Negeri Sipil (PNS) yang tidak menyadari akan tugas dan fungsinya tersebut sehingga seringkali timbul ketimpangan-ketimpangan dalam menjalankan tugasnya dan tidak jarang pula menimbulkan kekecewaan yang berlebihan pada masyarakat (Setiawan, 2006).

Hal yang tak perlu disangkal lagi, faktor kedisiplinan memegang peranan yang amat penting dalam pelaksanaan tugas sehari-hari para Pegawai. Seorang Pegawai yang mempunyai tingkat kedisiplinan yang tinggi akan tetap bekerja dengan baik walaupun tanpa diawasi oleh atasan. Seorang pegawai yang disiplin tidak akan mencuri waktu kerja untuk melakukan hal-hal lain yang tidak ada kaitannya dengan pekerjaan. Disiplin adalah meletakkan segala sesuatu pada setiap tempatnya. Bila tidak menjaga kedisiplinan maka akan mendapatkan beberapa masalah yang dapat mempengaruhi kinerja. Sebagai Pemimpin yang baik, disiplin itu harus ditanamkan dalam jiwa Pemimpin (Tampubolon, 2007).

Salah satu elemen yang bernilai penting dalam sistem manajemen selain disiplin kerja kepada para Pegawai adalah Kepemimpinan Diri. Kepemimpinan Diri adalah suatu proses dimana seseorang dapat menjadi Pemimpin (Leader) melalui aktivitas yang terus menerus sehingga dapat mempengaruhi yang dipimpinnya (followers) dalam rangka untuk mencapai tujuan organisasi (Suganda, 2001).

\section{SIMPULAN}

Gaya kepemimpinan dapat memberikan kontribusinya untuk meningkatkan kinerja karyawan yaitu 37,5\%. Artinya, besar sumbangan variabel gaya kepemimpinan terhadap kinerja karyawan adalah sebesar 37,5\%.

Disiplin kerja juga memberikan kontribusi yang cukup tinggi untuk meningkat kinerja karyawan yaitu 50,4\%. Artinya, besar sumbangan variabel disiplin kerja terhadap kinerja karyawan adalah sebesar 50,4\%.

Dari hasil korelasi dan regresi ganda atas gaya kepemimpinan, dan disiplin kerja secara bersama-sama dengan kinerja karyawan diperoleh besar koefisien korelasi sebesar 0,759 atau $57,6 \%$ kontribusi yang terjadi pada kinerja karyawan dapat dijelaskan secara bersama-sama melalui gaya kepemimpinan dan disiplin kerja melalui persamaan regresi tersebut. 


\section{DAFTAR PUSTAKA}

Aritonang, K. T. (2005). Kompensasi Kerja, Disiplin Kerja Guru dan Kinerja Gutu SMP Kristen BPK PENABUR. Jurnal Pendidikan Penabur, (4)

Fahmi, F. (2009). Analisis Pengaruh Disiplin Kerja dan Motivasi Kerja terhadap Kinerja Pegawai SPBU Pandanaran Semarang. Skripsi. Fakultas Ekonomi Universitas Gunadarma

Nurita, R. Y. P. (2008). Pengaruh Disiplin Kerja terhadap Kinerja Karyawan PT. Adira Finance Divisi Elektronik Cabang Bandung. Skripsi. Fakultas Bisnis dan Manajemen Universitas Widyatama

Paul, H., \& Blanchard, B. (2004). Manajemen Perilaku Organisasi. Jakarta: Erlangga

Setiyawan, B., \& Waridin, W. (2006). Pengaruh Disiplin Kerja Karyawan dan Budaya Organisasi terhadap Kinerja di Divisi Radiologi RSUP Dokter Kariadi Semarang. JRBI, 2(2), 181-198

Suganda, D. (2001). Kepemimpinan di dalam Organisasi Masyarakat. Bandung: Sinar Baru

Tampubolon, B. D. (2007). Analisis Faktor Disiplin Kerja dan Faktor Etos Kerja terhadap Kinerja Pegawai pada Organisasi yang Telah Menerapkan SNI 199001-2001. Jurnal Standardisasi, 9(3), 106-115 